\title{
Detection of mobile genetic elements in multidrug-resistant Klebsiella pneumoniae isolated from different infection sites in Hamadan, west of Iran
}

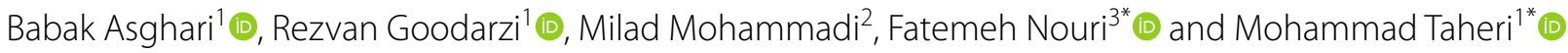

\begin{abstract}
Objective: Klebsiella pneumoniae is one of most opportunistic pathogens that can be related to nosocomial infections. Increased acquisitions of multidrug resistance in this bacterium as well as the transfer of genes to other strains have caused concern. Integrons play key role in the acquisition and the spread of resistance genes. The aim of this study was evaluated the frequency of resistance genes sull, sulll, tetA, tetB, class I (intl gene), class II integrons (intll gene) and the association between multidrug resistance and the presence of integrons in K. pneumoniae.

Results: Antibiotics susceptibility test was performed on 126 of $K$. pneumoniae isolates. Also, DNA extraction was done and genes were detected using PCR method. In this study, 67 isolates (53\%), carrying both the sull and sulll genes. Forty-five percent tetracycline-resistant isolates were tetA or tetB positive. The prevalence of int/ gene was $96 \%$, while only sixteen isolate harboring intl/ gene (12.5\%). Our results showed the high prevalence of integrons in MDR $K$. pneumoniae, indicating the important role of these genes in the transmission of antibiotic resistance.
\end{abstract}

Keywords: Mobile genetic elements, Multidrug-resistance, K. pneumoniae

\section{Introduction}

Klebsiella belongs to the Enterobacteriaceae family, which is known for causing human nosocomial infections such as urinary tract, intraabdominal, and upper respiratory tract infections (nosocomial pneumonia) [1,2]. Genes encode capsule, lipopolysaccharide, siderophores, and pili, which are all known virulence agents in K. pneumoniae. Virulence factors have recently been discovered as iron absorption systems, efflux pumps, and a type VI secretion system [3].

\footnotetext{
*Correspondence: Fatemenouri1@gmail.com; Motaheri360@gmail.com 1 Department of Medical Microbiology, Faculty of Medicine, Hamadan University of Medical Sciences, Hamadan, Iran

${ }^{3}$ Department of Pharmaceutical Biotechnology, School of Pharmacy,

Hamadan University of Medical Sciences, Hamadan, Iran

Full list of author information is available at the end of the article
}

Multidrug resistance has been increased globally that is considered public health threat. Several recent studies reported the emergence of multidrug-resistant bacterial pathogens from different origins including humans, poultry, cattle, and fish that increase the need for the proper application of antimicrobial agents as well as the routine application of the antimicrobial susceptibility testing to determine the antibiotic of choice [4-8]. Plasmids, transposons, and gene cassettes in integrons are examples of genetically engineered elements that contribute to antibiotic resistance [9].

Sulfonamides are antibiotics with a broad spectrum of action that are made chemically and used to treat bacterial infections [10]. In sulfonamide resistant strains, sul genes have been detected and provide translocation on chromosomes and plasmids are often associated with 
MGEs [11, 12]. Furthermore, plasmids harboring sul genes enable transfer among bacteria [13].

Integrons are genetic elements that include several genes and a special insertion site for the recombination system, enabling them to obtain mobile gene cassettes. Integrons are efficient systems in combining and expressing genes as part of their genetic elements known as gene cassettes $[14,15]$. Based on the genes that encode integrase enzymes, five classes of integrons have been identified, with classes I, II, and III being the most frequent [16, 17].

This study was aimed to detect of mobile genetic elements in multidrug-resistant $K$. pneumoniae isolated from different infection sites in Hamadan, west of Iran.

\section{Main text}

\section{Materials and methods}

\section{Bacterial isolates}

One hundred twenty-six clinical isolates of K. pneumoniae were isolated from patients admitted to the hospitals from August 2019 to January 2021 in Hamadan, west of Iran. After colony morphology and gram staining, the biochemical tests including indole, citrate, urease, and Kligler iron agar (KIA) tests are employed and API method were applied [18].

\section{Antimicrobial susceptibility testing}

Antimicrobial susceptibility test was performed using disk diffusion method in Muller Hinton Agar medium, according to CLSI 2019 instructions. Antibiotics included Amoxicillin/clavulanic acid $(30 \mu \mathrm{g})$, Cephalexin $(30 \mu \mathrm{g})$, Ceftazidime $(10 \mu \mathrm{g})$, Cefepime $(30 \mu \mathrm{g})$, Ceftriaxone $(30 \mu \mathrm{g})$, Cefoxitin $(30 \mu \mathrm{g})$, Sulfamethoxazole/ Trimethoprim (SXT 125/23.75 $\mu \mathrm{g}$ ), Imipenem $(10 \mu \mathrm{g})$, Aztreonam $(30 \mu \mathrm{g})$, Tetracycline $(30 \mu \mathrm{g})$, Moxifloxacin $(5 \mu \mathrm{g})$, Levofloxacin $(5 \mu \mathrm{g})$, Ciprofloxacin $(10 \mu \mathrm{g})$, Gentamicin $(10 \mu \mathrm{g})$, Amikacin $(30 \mu \mathrm{g})$, Tigecycline $(15 \mu \mathrm{g}) . K$. pneumoniae ATCC 3565 was the corresponding control in the experiments Antibiotics Classification used in the present study was shown in Additional file 1.

\section{DNA extraction and detection of genes}

The isolates were cultured in LB broth and incubated at $35^{\circ} \mathrm{C}$ overnight. The DNA concentration was determined using nanodrop. DNA amplification was performed in a thermal cycler (Apply biosystem, USA) using Mastermix (BioFact-Korea). The primers used in this study displayed in Table 1.

\section{PCR-based detection of antimicrobial resistance genes in the recovered $K$. pneumoniae isolates}

The PCR reaction mixture contained $1 \mu \mathrm{L}(10 \mathrm{pmol})$ of each primer, $2 \mu \mathrm{L}$ DNA, $25 \mu \mathrm{L}$ PCR Master Mix in a
Table 1 Primer sequences used in this study

\begin{tabular}{|c|c|c|c|}
\hline Gene & Primers sequence & Band size (bp) & References \\
\hline $\operatorname{tet} A$ & $\begin{array}{l}\text { F: GTGAAACCCAACATAC CCC } \\
\text { R: GAAGGCAAGCAGGATG TAG }\end{array}$ & 888 & {$[27]$} \\
\hline tet $B$ & $\begin{array}{l}\text { F: CCTTATCATGCCAGTCTTGC } \\
\text { R: ACTGCCGTTTTTTCGCC }\end{array}$ & 774 & {$[27]$} \\
\hline Sull & $\begin{array}{l}\text { F: CGGCGTGGGCTACCTGAACG } \\
\text { R: GCCGATCGCGTGAAGT TCCG }\end{array}$ & 433 & {$[36]$} \\
\hline Sulll & $\begin{array}{l}\text { F: GCGCTCAAGGCAGATGGCATT } \\
\text { R: GCGTTTGATACCGGCACCCGT }\end{array}$ & 293 & {$[36]$} \\
\hline Intl & $\begin{array}{l}\text { F: 5'-GCCTTGCTGTTCTTCTACGG-3' } \\
\text { R: 5'-GATGCCTGCTTGTTCTACGG-3' }\end{array}$ & 558 & {$[31]$} \\
\hline Int/l & $\begin{array}{l}\text { F: 5'-CACGGATATGCGACAAAA } \\
\text { AGGT-3' } \\
\text { R: 5'-GTAGCAAACGAGTGACGA } \\
\text { AATG-3' }\end{array}$ & 789 & {$[31]$} \\
\hline
\end{tabular}

total $50 \mu \mathrm{L}$ reaction volume. DNA amplification was conducted in a thermal cycler (Bio-Rad, USA), under the following conditions: initial denaturation at $94{ }^{\circ} \mathrm{C}$ for $5 \mathrm{~min}$, followed by 30 cycles of denaturation at $94{ }^{\circ} \mathrm{C}$ for $30 \mathrm{~s}$, annealing temperature for each gene for $40 \mathrm{~s}$, an extension at $72{ }^{\circ} \mathrm{C}$ for $45 \mathrm{~s}$, followed by a final extension at $72{ }^{\circ} \mathrm{C}$ for $4 \mathrm{~min}$. The amplified DNA fragments, along with a $100 \mathrm{bp}$ DNA size marker was run on $2 \%$ agarose gel electrophoresis.

\section{Statistical analysis}

The t-test was used to compare categorical results. All statistical tests were two-tailed, and statistical significance was defined as a P-value of 0.05 . The statistical software package SPSS version 22 (IBM, NY) was used to analyze the data.

\section{Results}

\section{Antibiotic resistance pattern}

Frequency of samples obtained were UTI 39 (31\%), Sputum 38 (29.9), Tracheal 29 (23\%), Wound 16 (12.6\%) and BAL 4 (3.4\%). The highest frequency of resistance to antimicrobial agents related to gentamicin $(58.6 \%)$ and lowest to meropenem (4.6\%) is shown in Fig. 1. In the present study, MDR was predominant among $K$. pneumoniae isolates because $58.6 \%$ of the isolates were MDR. The frequency of ESBL producing isolates was $52.9 \%$. The frequency of samples in different parts of the body is shown in Fig. 2 according to MDR and non-MDR classification.

\section{Frequency of genes and antibiotic susceptibility test}

In this study, $51.7 \%$ of isolates were resistant to sulfamethoxazole/trimethoprim (SXT) which of $60.9 \%$ isolates harboring sulI and 26.4\%had sulII gene. A significant 


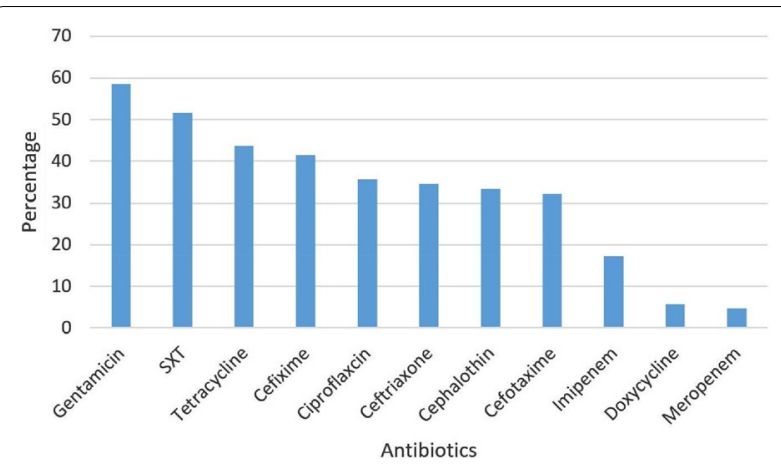

Fig. 1 The highest frequency of resistance to antimicrobial agents

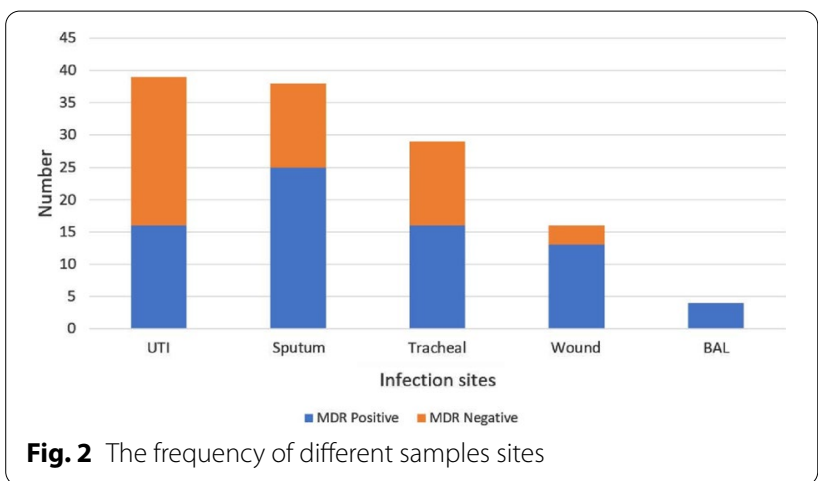

relationship was seen only between sulI and SXT resistance $(\mathrm{P}=0.008)$.

Fifty-five (43.7\%) isolates were tetracycline resistant; among them $23 \%$ and $12.6 \%$, isolates were positive for tet $A$ and tet $B$ genes, respectively. There was a significant relationship between the presence of these genes and tetracycline resistance $(\mathrm{P}<0.01)$.

The prevalence of int 1 and int 2 genes among isolates were $102(81.6 \%)$ and $50(40.2 \%)$, respectively. The relationship between the presence of int2 gene with ESBL producing, sulI, tetA, and MDR isolates was significant. The presence of int2 gene and resistance to all antibiotics used in this study was significant $(\mathrm{P}<0.01)$. The relationship between MDR and ESBL producing isolates with resistance to all antibiotics used in this study was significant $(\mathrm{P}<0.001)$.

\section{Discussion}

Due to the increase in antibiotic resistance, awareness of microbial resistance pattern and mechanisms of resistance transmission among bacterial infections can be an effective strategy to prevent microbial resistance transmission [19].

This study showed that there was a high level of antimicrobial resistance among $K$. pneumoniae isolates. More than $30 \%$ of the $126 \mathrm{~K}$. pneumoniae isolates tested in this study demonstrated resistance to antimicrobials such as sulfamethoxazole/trimethoprim, tetracycline, ciprofloxacin, gentamicin, tetracycline, cefixime, cephalothin, ceftriaxone, and cefotaxime. The results of our study are consistent with the results of many past studies, which show a relatively high prevalence of $K$. pneumoniae resistant isolates in hospital settings. Moghadampour et al. showing resistance to gentamicin (30\%), ceftazidime (34\%), sulfamethoxazole/trimethoprim (22\%), and ciprofloxacin (27\%) have been reported in Iran [20].

In this investigation, $58.6 \%$ of $K$. pneumoniae isolates were MDR, which is higher than what has been reported in Kenya [21], but lower than what has been reported in China [22]. The results of this study, antibiotic resistance are similar to the results of Zomorodi et al. [23] in 2019, although the production of ESBL gene in our study is $52.9 \%$, which shows an increase compared to their study which could indicate the transfer of genetic elements between bacteria and increased resistance to the ESBL gene.

In a 2021 study by Fatima et al.[24], among SXT-resistant strains, the frequency of sulI (66.7\%) gene was similar to our study (60.9\%). Although all of the tetracyclineresistant strains had the $\operatorname{tet} B$ gene, in our study only there was $12.6 \%$ of tet $B$ gene that could indicate other mechanisms in the development of tetracycline resistance in bacteria.

The majority of MDR K. pneumoniae examined tested were positive for integron class 1 . A high correlation has been established between the presence of integron class 1 and the prevalence of MDR in gram-negative bacteria. In a study of $\mathrm{Li}$ et al., integron 1 positive isolated bacteria showed a much higher incidence of drug resistance than negatively ones [25]. Other studies have shown a high prevalence of positive integron MDR-K. pneumoniae. The high prevalence of integron among MDR strains maybe since integron has the advantage of selective stress selection of strains in environments such as hospitals, which are caused by antibiotic abuse [26].

In our study, beta-lactam resistance was $88 \%$, which compares with the results reported by Khamesipour et al. [27]. Tetracycline resistance is a common resistance among bacteria and its resistance was $43.7 \%$ among our isolates. In quinolone (ciprofloxacin) resistance (35.6\%) among our isolates, they are much higher than reported in China [28], Iran [27], and India [29]. Aminoglycoside resistance has been reported to be the highest among antibiotics with a resistance rate of $58.6 \%$. The data related to Tanzania and Kenya were higher for gentamicin compared with our study.

The result of PCR assay for tetracycline-resistant $K$. pneumoniae isolates and the frequency of genes reported 
to tet $A$ or $\operatorname{tet} B$ was $23 \%$ and $12.6 \%$, respectively. In Iran, Khamesipour et al. reported that tetB percentage (64.1\%) and a higher percentage of tet $A(79.4 \%)$, while the results of Bocaine et al. showed that all tetracycline-resistant $K$. pneumoniae isolates contained both the tet $A$ and tet $B$ genes. Previous studies have shown that tet $B$ was in highly motile genetic elements that are easily transmitted between different bacterial genera. The association between tetracycline resistance genes $(\operatorname{tet} A$ and tet $B)$ and class II integrons (intII) among our isolates suggests that class II integrons may be associated with the release of both tetracycline resistance genes. Similarly, Rezaei et al. reported a positive association between the presence of intI and intII genes and tetracycline resistance [30]. Our results show that integrons are widespread in isolated $K$. pneumoniae. Among the 126 isolates were int1 (81.6\%) and int2 (40.2\%), indicating high integrons presence. In this study, a significant relationship was also found $(\mathrm{P}<0.001)$ between MDR phenotype and integrons, while Martinez Freijou et al. only described the tendency to develop resistance to several antimicrobial agents in strains with integrons. In this study, $81.6 \%$ of class I integron strains was observed, Derkhshan et al. that I integron was $25.8 \%$, which shows a significant difference that can be found in the Derkhshan et al., of the majority of K. pneumoniae were isolated from urine [31]. In the present study, the integron class II with all antibiotics used was statistically significant, which could indicate antibiotic resistance due to integron class II. The prevalence of class 2 integrons in our MDR K. pneumoniae isolates was $40.2 \%$, which is higher than that described by Rezaei et al. [30] and Firoozeh et al. [32] in northwestern and central Iran.

The frequency distributions of both sulI and sulII genes among sulfamethoxazole/trimethoprim-resistant isolates were $60.9 \%$ and $26.4 \%$, respectively. This may be due to the widespread release of class 1 integron, which are closely related to the sulI gene.

As a common factor in the widespread dissemination of antimicrobial resistance genes, the prevalence of class 1 integrons has been reported to be 22 to $59 \%$. In this study, the prevalence of class 1 integrons among clinical isolates of K. pneumoniae was $90 \%$. Approximately similar frequencies of class 1 integrons have been reported in India (92\%) and in China (93.2\%). On the other hand, Class 1 integrons are less prevalent in other parts of world, including Brazil (65.5\%) [33], Iran (66.6\%) [27], Australia (73\%) [34], United States (78.5\%). and Korea (73.3\%) [35].

Our study found a strong association between the presence of class II integrons and resistance to all antibiotics $(\mathrm{P}<0.01)$. Class II integrons have generally been reported to be less common in some gram-negative organisms.
Monitoring the changes of integron gene cassettes in $K$. pneumoniae population can prevent the spread of antibiotic resistance factors in hospitals. Periodic monitoring and identification of these elements can help reduce disease burden, reduce costs, and shorten hospital stays. Overall, this study showed that carbapenems and doxycycline are the most effective antibiotics against $K$. pneumoniae. The high frequency of class I and II integron and the presence of MDR K. pneumoniae isolates is a serious warning for health authorities.

\section{Conclusion}

Statistical relationships between drug resistance and integrons show that integrons are the encoder and disseminator of drug resistance among $K$. pneumoniae isolates. Mobile genetic elements are undeniable among bacteria as a natural phenomenon and bacteria become resistant to antibiotics in this way, it is necessary that with rational use of antibiotics also modifications in the pattern of antibiotics administered by physicians, be applied periodically.

\section{Limitation}

Due to financial and time constraints in this research, the evaluation of several genes and also achieving more samples in various geographical locations in the country didn't done and are among the limitations of this study. PCR-based detection of the most common virulence genes of $K$. pneumoniae should be carried out.

\section{Abbreviations}

CLSI: Clinical and laboratory standards institute; TSB: Tryptic soy broth; OD: Optical density; PCR: Polymerase chain reaction.

\section{Supplementary Information}

The online version contains supplementary material available at https://doi. org/10.1186/s13104-021-05748-9.

Additional file 1. Antibiotics Classification used in the present study.

\section{Acknowledgements}

The authors would like to acknowledge the Vice-chancellor of Research and Technology, Hamadan University of Medical Sciences, Hamadan, Iran.

\section{Authors' contributions}

Substantial contributions to conception and design, and/or acquisition of data, and/or analysis and interpretation of data, drafting the article: All Authors; revising it critically for important intellectual content: MT \& BA; approved the version to be submitted and revised the text: RG, MM and FN. All authors read and approved the final manuscript.

\section{Funding}

Hamadan University of Medical Sciences, Hamadan, Iran, financially supported the study. 


\section{Availability of data and materials}

The datasets used and/or analyzed during the current study available from the corresponding author on reasonable request.

\section{Declarations}

\section{Ethics approval and consent to participate}

This study has been supported financially by the Hamadan University of Medical Sciences. Informed written consent (in Persian) was given to subjects from whom the samples were obtained for this study (IR.UMSHA.REC.1400.381).

\section{Consent for publication}

Not applicable.

\section{Competing interests}

There are no conflicts of interest.

\section{Author details}

${ }^{1}$ Department of Medical Microbiology, Faculty of Medicine, Hamadan University of Medical Sciences, Hamadan, Iran. ${ }^{2}$ Student Research Committee, Hamadan University of Medical Sciences, Hamadan, Iran. ${ }^{3}$ Department of Pharmaceutical Biotechnology, School of Pharmacy, Hamadan University of Medical Sciences, Hamadan, Iran.

\section{Received: 20 May 2021 Accepted: 17 August 2021}

Published online: 26 August 2021

\section{References}

1. Chung PY. The emerging problems of Klebsiella pneumoniae infections: carbapenem resistance and biofilm formation. FEMS Microbiol Lett. 2016;363:fnw219.

2. Nouri F, Karami P, Zarei O, Kosari F, Alikhani MY, Zandkarimi E, Zarandi ER, Taheri M. Prevalence of common nosocomial infections and evaluation of antibiotic resistance patterns in patients with secondary infections in Hamadan, Iran. Infect Drug Resist. 2020;13:2365.

3. Ahmad A, Khan A, Akhtar F, Yousuf S, Xess I, Khan L, Manzoor N. Fungicidal activity of thymol and carvacrol by disrupting ergosterol biosynthesis and membrane integrity against Candida. Eur J Clin Microbiol Infect Dis. 2011;30:41-50.

4. Alvarez-Uria G, Gandra S, Mandal S, Laxminarayan R. Global forecast of antimicrobial resistance in invasive isolates of Escherichia coli and Klebsiella pneumoniae. Int J Infect Dis. 2018;68:50-3.

5. Makharita RR, El-Kholy I, Hetta HF, Abdelaziz MH, Hagagy Fl, Ahmed AA, Algammal AM. Antibiogram and genetic characterization of carbapenem-resistant gram-negative pathogens incriminated in healthcareassociated infections. Infect Drug Resist. 2020;13:3991.

6. Kareem SM, Al-Kadmy IM, Kazaal SS, Ali ANM, Aziz SN, Makharita RR, Algammal AM, Al-Rejaie S, BehI T. Batiha GE-S: detection of gyra and parc mutations and prevalence of plasmid-mediated quinolone resistance genes in Klebsiella pneumoniae. Infect Drug Resist. 2021;14:555.

7. Algammal AM, Mabrok M, Sivaramasamy E, Youssef FM, Atwa MH, El-Kholy AW, Hetta HF, Hozzein WN. Emerging MDR-Pseudomonas aeruginosa in fish commonly harbor opr $L$ and tox $A$ virulence genes and bla TEM, bla CTX-M, and tet A antibiotic-resistance genes. Sci Rep. 2020;10:1-12

8. Abolghait SK, Fathi AG, Youssef FM, Algammal AM. Methicillin-resistant Staphylococcus aureus (MRSA) isolated from chicken meat and giblets often produces staphylococcal enterotoxin B (SEB) in non-refrigerated raw chicken livers. Int J Food Microbiol. 2020;328:108669.

9. Bello-López JM, Cabrero-Martínez OA, Ibáñez-Cervantes G, HernándezCortez C, Pelcastre-Rodríguez LI, Gonzalez-Avila LU, Castro-Escarpulli G. Horizontal gene transfer and its association with antibiotic resistance in the genus aeromonas spp. Microorganisms. 2019;7:363.

10. Shokoohizadeh L, Saniee M, Mirzaee M, Taheri M. Mutations in gyrA and parC genes in quinolone-resistant Klebsiella pneumoniae isolates from borujerd hospitals. J Adv Med Biomed Res. 2019;27:1-7.

11. Rehman MU, Zhang H, Huang S, lqbal MK, Mehmood K, Luo H, Li J. Characteristics of integrons and associated gene cassettes in antibiotic-resistant Escherichia coli isolated from free-ranging food animals in China. J Food Sci. 2017;82:1902-7.

12. Wu S, Dalsgaard A, Hammerum AM, Porsbo LJ, Jensen LB. Prevalence and characterization of plasmids carrying sulfonamide resistance genes among Escherichia coli from pigs, pig carcasses and human. Acta Vet Scand. 2010;52:1-7.

13. Kemp K, Griffiths J, Campbell S, Lovell K. An exploration of the follow-up up needs of patients with inflammatory bowel disease. J Crohns Colitis. 2013;7:e386-95.

14. Subirats J, Timoner X, Sànchez-Melsió A, Balcázar JL, Acuña V, Sabater S, Borrego CM. Emerging contaminants and nutrients synergistically affect the spread of class 1 integron-integrase (intl1) and sul 1 genes within stable streambed bacterial communities. Water Res. 2018;138:77-85.

15. Fuga B, Royer S, Campos PA, Ferreira ML, Rossi I, Machado LG, Cerdeira LT, Fonseca Batistão DW, Brito CS, Lincopan N. Molecular detection of class 1 integron-associated gene cassettes in KPC-2-producing Klebsiella pneumoniae clones by whole-genome sequencing. Microbial Drug Resist. 2019;25:1127-31.

16. Gillings MR. Integrons: past, present, and future. Microbiol Mol Biol Rev. 2014;78:257-77.

17. Ghaly TM, Geoghegan JL, Tetu SG, Gillings MR. The peril and promise of integrons: beyond antibiotic resistance. Trends Microbiol. 2020;28:455-64.

18. Osman EA, El-Amin N, Adrees EA, Al-Hassan L, Mukhtar M. Comparing conventional, biochemical and genotypic methods for accurate identification of Klebsiella pneumoniae in Sudan. Access Microbiol. 2020;2:acmi000096.

19. Sedighi P, Zarei O, Karimi K, Taheri M, Karami P, Shokoohizadeh L: Molecular Typing of Klebsiella pneumoniae Clinical Isolates by Enterobacterial Repetitive Intergenic Consensus Polymerase Chain Reaction. Int J Microbiol. 2020, 2020.

20. Moghadampour M, Salari-Jazi A, Faghri J. High rate of carbapenemresistant Klebsiella pneumoniae detected from hospital equipments in Iran. Acta Microbiol Immunol Hung. 2018;65:529-38.

21. Taitt CR, Leski TA, Erwin DP, Odundo EA, Kipkemoi NC, Ndonye JN, Kirera RK, Ombogo AN, Walson JL, Pavlinac PB. Antimicrobial resistance of Klebsiella pneumoniae stool isolates circulating in Kenya. Plos ONE. 2017;12:e0178880.

22. Hou X, Song X, Ma X, Zhang S, Zhang J. Molecular characterization of multidrug-resistant Klebsiella pneumoniae isolates. Brazil J Microbiol. 2015;46(3):759-68.

23. Zomorrodi A, Zargar M, Noroozi J. Evaluation of antibiotic resistance associated with ophthalmic oqXAB pumps in Klebsiella pneumoniae causing urinary tract infection. Medi Sci J Islam Azad Univ Tehran Medi Branch. 2019;29:163-70.

24. Fatima S, Liaqat F, Akbar A, Sahfee M, Samad A, Anwar M, lqbal S, Khan SA Sadia H, Makai G. Virulent and multidrug-resistant Klebsiella pneumoniae from clinical samples in Balochistan. Int Wound J. 2021;18(4):510-8.

25. Li B, Hu Y, Wang Q, Yi Y, Woo PC, Jing H, Zhu B, Liu CH. Structural diversity of class 1 integrons and their associated gene cassettes in Klebsiella pneumoniae isolates from a hospital in China. PloS ONE. 2013;8:e75805.

26. Wu K, Wang F, Sun J, Wang Q, Chen Q, Yu S, Rui Y. Class 1 integron gene cassettes in multidrug-resistant Gram-negative bacteria in southern China. Int J Antimicrob Agents. 2012;40:264-7.

27. Khamesipour F, Tajbakhsh E: Analyzed the genotypic and phenotypic antibiotic resistance patterns of Klebsiella pneumoniae isolated from clinical samples in Iran. 2016.

28. Zhang X, Chen D, Xu G, Huang W, Wang X. Molecular epidemiology and drug resistant mechanism in carbapenem-resistant Klebsiella pneumoniae isolated from pediatric patients in Shanghai, China. PLOS ONE. 2018;13:e0194000.

29. Tiwari DK, Golia S, Sangeetha K, Vasudha C. A study on the bacteriological profile and antibiogram of bacteremia in children below 10 years in a tertiary care hospital in Bangalore, India. J Clin Diagn Res JCDR. 2013;7:2732.

30. Rezaee MA, Langarizadeh N, Aghazadeh M. First report of class 1 and class 2 integrons in multidrug-resistant Klebsiella pneumoniae isolates from northwest Iran. Jpn J Infect Dis. 2012;65:256-9.

31. Derakhshan S, Najar Peerayeh S, Fallah F, Bakhshi B, Rahbar M, Ashrafi A. Detection of class 1, 2, and 3 integrons among Klebsiella pneumoniae isolated from children in Tehran hospitals. Arch Pediatric Infect Dis. 2014;2:164-8. 
32. Firoozeh F, Mahluji Z, Khorshidi A, Zibaei M. Molecular characterization of class 1, 2 and 3 integrons in clinical multi-drug resistant Klebsiella pneumoniae isolates. Antimicrob Resist Infect Control. 2019;8:1-7.

33. Lima AMS, Melo MES, Alves LC, Brayner FA, Lopes ACS. Investigation of class 1 integrons in Klebsiella pneumoniae clinical and microbiota isolates belonging to different phylogenetic groups in Recife, State of Pernambuco. Revista da Sociedade Brasileira de Medicina Tropical. 2014;47:165-9.

34. Jones LA, Mclver CJ, Kim M-J, Rawlinson WD, White PA. The aadB gene cassette is associated with blaSHV genes in Klebsiella species producing extended-spectrum $\beta$-lactamases. Antimicrob Agents Chemother. 2005;49:794-7.

35. Shin HW, Lim J, Kim S, Kim J, Kwon GC, Koo SH. Characterization of trimethoprim-sulfamethoxazole resistance genes and their relatedness to class 1 integron and insertion sequence common region in gram-negative bacilli. J Microbiol Biotechnol. 2015;25:137-42.

36. Gündoğdu A, Long YB, Vollmerhausen TL, Katouli M. Antimicrobial resistance and distribution of sul genes and integron-associated intl genes among uropathogenic Escherichia coli in Queensland, Australia. J Med Microbiol. 2011;60:1633-42.

\section{Publisher's Note}

Springer Nature remains neutral with regard to jurisdictional claims in published maps and institutional affiliations.
Ready to submit your research? Choose BMC and benefit from:

- fast, convenient online submission

- thorough peer review by experienced researchers in your field

- rapid publication on acceptance

- support for research data, including large and complex data types

- gold Open Access which fosters wider collaboration and increased citations

- maximum visibility for your research: over $100 \mathrm{M}$ website views per year

At BMC, research is always in progress.

Learn more biomedcentral.com/submissions 